\title{
Air traffic will take years to return to 2019 levels
}

\author{
Wednesday, July 8, 2020 \\ Commercial airlines are starting to emerge from the greatest downturn in traffic and \\ grounding of fleets on record
}

Passenger airlines are stepping up operations as the developed world emerges from lockdown. However, it remains uncertain how evolving measures to curb the spread of COVID-19 will affect their operations, how long it will take for consumer confidence to recover, and perhaps most importantly, whether the average of two months' cash reserves airlines had going into this crisis will see them through it.

\section{What next}

Airlines are expected to lose roughly one-third of their 2019 revenues this year, with global passenger numbers down sharply. Domestic traffic will rebound first, followed by inter-regional and then intercontinental traffic. This puts European and Middle Eastern airlines at a disadvantage to Asian and North American ones. Exploiting freight opportunities will be key to airlines' fortunes, as passenger numbers might not recover fully until 2024.

\section{Subsidiary Impacts}

- Aviation suppliers including airports and aircraft manufacturers are forecast to suffer heavy losses.

- The world recession will hit consumer and business confidence, and disposable incomes, slowing the passenger and cargo traffic recovery.

- The UNWTO sees world tourism sales falling by $73 \%$ this year, hitting the many nations that rely on tourism as a key engine of GDP growth.

\section{Analysis}

Many governments have offered temporary wage support for workers and emergency loans for companies, to cushion the impact of the downturn on travel and aviation.

Most airlines have contracted to survive. UK airlines British Airways and Virgin Atlantic have used the national furlough scheme, have retired older aircraft earlier than planned, and temporarily closed bases including London Gatwick. German airline Lufthansa announced last month that it would cut 22,000 jobs, or $16 \%$ of its end-2019 workforce, having agreed a EUR9bn (USD10.2bn) bailout with the government in May and wound up its Germanwings operation in April. Even more profitable airlines, such as Ryanair, have found it untenable to sustain such large fixed costs at a fraction of pre-pandemic income.

\section{Taskforces}

As the summer peak season begins in Europe and North America, lower forward bookings are sending jitters through airline boardrooms (see INTERNATIONAL: Tourism will settle to a new normal June 8,2020 ). Although Europe is reopening and case numbers have fallen, a return to normality is a long way off. The chief executives of Ryanair and Heathrow Airport have suggested that it will be impossible to implement social distancing measures, leading to consternation about the prospects for recovery without an effective vaccine or treatment.

The International Civil Aviation Organization (ICAO), the International Air Traffic Association (IATA) and Airports Council International have set up taskforces to guide airlines, airports and policymakers. The ICAO published its guidance on May 27, though the implementation of its recommendations has been inconsistent.

Measures taken revolve around minimising the risk of spreading the virus, including COVID-19 testing 
on arrival with results available within two hours (in Austria) and the opening of borders limited to countries deemed to have better managed the coronavirus outbreak (the EU's 'safe' list of 14 countries outside its borders) (see INTERNATIONAL: Travel deals will face reversals - June 16, 2020). Other measures being implemented include temperature screening, compulsory use of facemasks by staff and travellers, social distancing, expedited implementation of biometrics at airports, reminders about the importance of hygiene and social distancing, automated contact tracing of those that test positive for the virus and enhanced sanitisation of aircraft and airport equipment.

These measures will cushion the reduction in confidence in air travel.

Passenger air traffic in 2020 (billions of people)

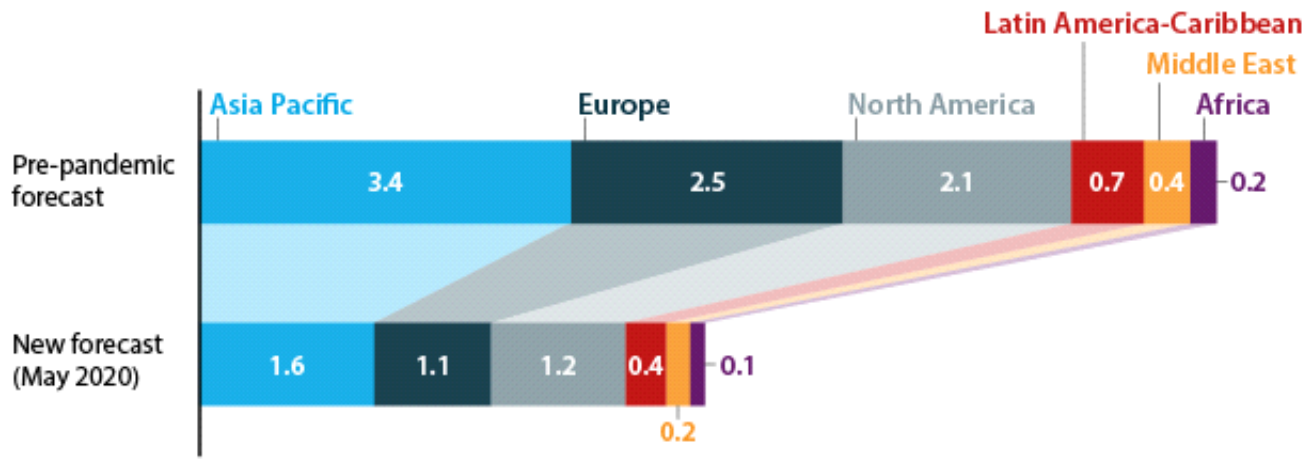

Source: ACI Economic impact assessment of COVID-19 on the airport business, May 52020

\section{Cargo activity}

Air cargo traffic has not fallen as steeply as passenger business as the distribution of essential supplies including food, cleaning equipment, personal protective equipment, high-value electronics and medicine and pharmaceutical products has continued.

Preliminary ICAO analysis indicates that global belly cargo (carried below the passenger cabins of aircraft configured for passenger and freight operations) fell by $30 \%$ year-on-year in March to 2.4 million tonnes. All-freighter traffic (carried on aircraft configured for freighter operations) rose by $9 \%$ year-onyear to 1.6 million tonnes. The need for specialised charters to carry essentials in high quantities has driven more all-freighter traffic.

\section{$9 \%$}

\section{All-freighter (cargo) air traffic grew in March}

Overall air cargo traffic fell by $19 \%$ year-on-year in March and revenues by $22 \%$ year-on-year. According to the IATA, April 2020 represented the low point for cargo and May saw the first signs of a rebound.

The pandemic is demonstrating the important role air freight plays in delivering time-sensitive, highvalue products efficiently, something often forgotten as discretionary and leisure travel segments are more visible and tangible.

Many of the world's passenger-focused airlines and airports will be taking note and considering how they can diversify their revenue streams to help cushion the impact of future downturns. Qatar Airways has pursued an aggressive growth strategy for its cargo business, developing 28 all-freighter aircraft, and taking advantage of the grounding of passenger fleets to utilise its dedicated fleet of wide body allfreighter aircraft. Also a large passenger airline, Qatar Airways is the world's second-largest cargo carrier by tonne kilometres after FedEx.

Freight could provide essential revenues for many airlines until new COVID-19 cases fall sustainably and governments are better able to handle spikes. 
This activity will provide enough work for some pilots, engineers and cabin crew to prevent the expiry of licences. It will also allow airlines to rotate some of their grounded aircraft, keeping them airworthy and avoiding higher maintenance costs later.

Involvement in essential cargo, repatriation, humanitarian and charter operations will help airlines to develop competencies as some of these sectors will be new to them.

\section{Outlook}

As some regions ease lockdowns, it is becoming clear that countries and regions which are more geared towards long-distance intercontinental markets will take longer to recover. Europe and Middle Eastern airlines rely on intercontinental traffic. Conversely, as much as $89 \%$ of air traffic in the AsiaPacific region is either domestic (66\%) or intra-regional (23\%). This partly explains the quicker recovery in countries such as China (which is now back to two-thirds of pre-pandemic traffic). In North America, $84 \%$ of traffic is domestic and a large share of this will be able to return as soon as containment measures curb the spread of COVID-19.

\section{Breakdown of domestic and international passenger air traffic, 2018 (\%)}

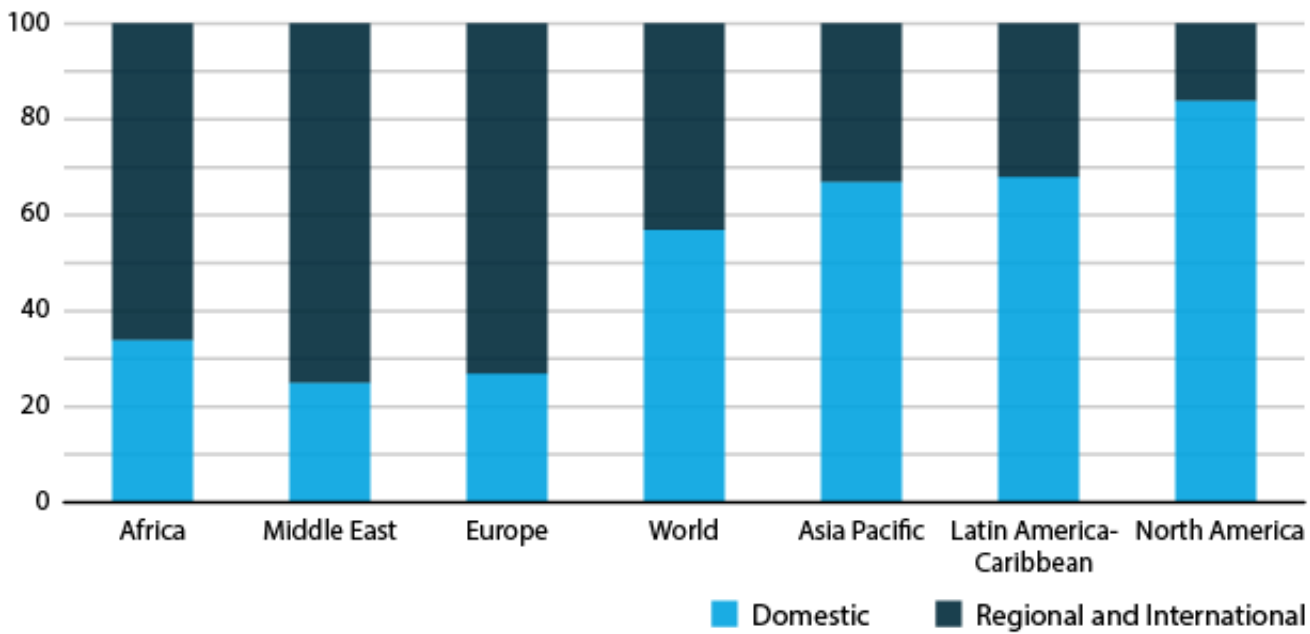

Source: ACI Economic impact assessment of COVID-19 on the airport business, May 52020 For many individual businesses in Europe and North America, the short-term task will be to regain at least some revenue during the summer season. July-September is a busy quarter for air traffic, accounting for $31 \%$ of Europe's annual total. The Middle East and Asia experience less seasonal variation.

With COVID-19 cases still rising in the Americas, South Asia, Africa and the Middle East, the prospects of a strong rebound in the third and fourth quarters look tenuous. Most practitioners and experts agree that the industry will not see traffic return to 2019 levels until 2024 or later (see INTERNATIONAL: Aerospace business models may change - June 1,2020).

\section{$25 \%$ \\ Government bailout for US-based airlines as percentage of annual revenues}

Government bailout packages will influence the new landscape. By June 2020, USD123bn of state aid had been given to the world's airlines, equal to $25 \%$ of airline revenues in the United States, $15 \%$ in Europe and around 1\% for carriers based in each of Latin America, Africa and the Middle East (state ownership is higher in these regions). 